\title{
Montessori Yaklaşımı Temelli STEM Etkinliklerinin Öğretmen Adaylarının Fene ve Fen Öğretimine Yönelik Tutumlarına Etkisi
}

DOI: $10.26466 /$ opus.831879

\author{
Zehra Cakır * - Sema Altun Yalçın ** \\ * Erzincan Binali Yıldırım Üniversitesi Fen Bilimleri Enstitüsü \\ E-Posta: zehracakir.29@hotmail.com \\ ORCID: 0000-0003-4585-8214 \\ ** Prof. Dr., Erzincan Binali Yıldırım Üniversitesi \\ E-Posta: saltun 11@hotmail.com \\ ORCID: $\underline{0000-0001-6349-2231}$
}

\begin{abstract}
$\ddot{O} z$
Bu çalışmada, Montessori eğitim yaklaşımı felsefesi temel alınarak hazırlanan STEM etkinliklerinin okul öncesi öğretmen adaylarının fene ve fen öğretimine yönelik tutumlar üzerindeki etkisini tespit etmek amaçlanmıştır. Çalışmada karma yöntem kullanılmıştır. Örneklem grubu toplamda 50 okul öncesi öğretmen adayından oluşmaktadır. Çalışmada nicel verileri toplamak için tek grup öntest sontest deseni oluşturulmuştur. Çalışma toplamda 14 hafta sürmüştür. Çalışmada nicel veri toplama araçları olarak "Fen Öğretimine Yönelik Tutum Ölçeği" ve "Fen Bilgisi Tutum Ölçeğgi" kullamılmıştır. Çalışmanın nitel verilerini toplamak için de nicelde kullanılan ölçeklerin maddeleri temel alnarak araştırmacı tarafından hazırlanan "Yarı yarı yapılandırılmış mülakat formu" kullanılmıştır. Çalışmada elde edilen nicel veriler istatistiksel (paired sample $t$ testi) yöntemle, nitel veriler ise içerik analizi ile analiz edilmiştir. Çalışma sonucunda; Montessori yaklaşım temelli STEM etkinliklerinin okul öncesi öğretmen adaylarının fene ve fen öğretimine yönelik tutumları üzerinde olumlu yönde etki ettiği tespit edilmiştir. Nitel verilerde elde edilen sonuçlarda ö̆gretmen adaylarmm fene ve fen öğretmeye yönelik tutumlarında olumlu gelişmeler sağladığın ve nicel sonuçları destekler nitelikte olduğunu göstermiştir.
\end{abstract}

Anahtar Kelimeler: Fen, Montessori yaklaşımı, STEM, Tutum 


\title{
The Effects of Montessori Approach Based STEM Activities on Pre-service Teachers' Attitudes Towards Science and Science Teaching
}

\begin{abstract}
In this study, it was aimed to determine the effect of STEM activities prepared on the basis of the Montessori education approach philosophy on pre-school teacher candidates' attitudes towards science and science teaching. Mixed method was used in the study. The sample group consists of 50 pre-school teacher candidates in total. In the study, a single group pre-test post-test pattern was created to collect quantitative data. The study lasted 14 weeks in total. In the study, "Science Attitude Scale" and "Science Attitude Scale" were used as quantitative data collection tools. In order to collect the qualitative data of the study, the "semi-structured interview form" prepared by the researcher based on the items of the scales used in quantitative terms was used. The quantitative data obtained in the study were analyzed using the statistical (paired sample $t$ test) method, and the qualitative data were analyzed by content analysis. In the results of working; It has been determined that STEM activities based on Montessori approach have a positive effect on pre-school teacher candidates' attitudes towards science and science teaching. The results obtained from the qualitative data showed that there were positive improvements in teacher candidates' attitudes towards science and science teaching and the quantitative results were of high quality.
\end{abstract}

Keywords: Science, Montessori approach, STEM, Attitude 


\section{Giriş}

Teknolojinin hızla geliştiği bilim çağında ülkelerin ihtiyaç ve beklentilerini karşılayabilecek nitelikli bireylerin yetiştirilmesini gerekli kılmıştır. Bu da eğitim programlarında fen eğitiminin etkili bir şekilde gerçekleştirilmesiyle mümkündür. Fen eğitimi için eğitim ortamları ne kadar iyi tasarlanırsa bireylerin feni kalıcı ve etkili bir şekilde öğrenebilmeleri de o kadar iyi olacaktır (Smith ve Karr-Kidwell, 2000). Feni öğrenen bireyler bunu diğer disiplinlerle birleştirerek günlük hayatlarında kullanabileceklerdir. Bunu sağlayan eğitim programı ise dünyada yaygın olarak kullanılan, Türkiye' de ise 2017 yılından itibaren müfredata katılan, STEM eğitimidir (Bybee, 2010; Çepni, 2017). Fenin tek başına etkili bir şekilde verilmesinin yeterli olmadığını gören ülkeler, feni diğer disiplinlerle yani teknoloji, matematik ve mühendislik alanları ile entegre bir şekilde verilmesi gerektiğinin önemini vurgulamışlardır. Bu dört ana disiplinin birbiriyle entegre edilmesi de STEM eğitimini ortaya çıkarmıştır (TÜSİAD, 2014).

21. yüzyılda bilimsel gelişmeye öncülük eden matematik ve fen bilimleri eğitimlerinin etkinleştirilmesi, birçok ülkenin eğitim sistemlerindeki temel hedefi haline gelmiştir. Yine yaşamın her yerinde fen ve teknoloji olmasına rağmen çocuklara yeteri kadar bu alanlarda deneyimler sunulmamaktadır. Tam bu noktada okul öncesi eğitim programı ile kolayca bütünleştirilerek disiplinler arası bağı kurmayı ve bu deneyimleri sağlayabilecek; teknoloji, fen, mühendislik ve matematiği içinde barındıran STEM yaklaşımı daha da önem kazanmaktadır (Ünlü ve Dere, 2018). Okul öncesi eğitim araştırmacıları bu alanların önemini vurgulayarak çocukların sorgulama ve araştırma yoluyla öğrenmelerini desteklemektedirler (Linder, Ramey ve Zambak, 2013). STEM üzerinde yapılan çalışmalar, son zamanlarda okul öncesi (anaokulu) dönem üzerine odaklanmıştır. Literatüre bakıldığında okul öncesinde; STEM eğitiminin içinde bulunan fen, ve matematik eğitimlerinin, çocukların seviyelerine uygun olmasının yanı sıra 21. yy becerilerini kazandırmada daha etkili olduğu görülmüştür. Ayrıca okul öncesi dönemdeki çocukların yaratıcılık becerilerinin maksimum seviyede olması, STEM uygulamalarının bu dönemde verilmesinin hedef ve kazanımlara ulaşmada önemli bir etki olarak görülmektedir (Greenfield vd., 2009; Sackes Flevares, Gonya ve Trundle, 2012). Bu düşünce doğrultusunda yapılan çalışmalar, okul öncesi eğitim-öğretiminde fen ve matematik eğitimleri üzerine odaklanmış ve uygulamalı 
STEM etkinliklerini ortaya çıarmıştır. Daha sonra bu STEM etkinliklerinin, okul öncesi dönem eğitiminde kullanılan ve STEM'le ortak amaçları barındıran Montessori yaklaşımıyla harmanlanarak uygulatılmasının çocuğa hem farklı disiplinlerin kolaylıkla öğretilmesini hem de sağlayacağı katkının önemi üzerindeki görüşü ortaya çıkarmıştır (Çakır, Altun Yalçın ve Yalçın, 2020). Okul öncesinde oynatılan oyunlar, çocuğa kazandırılmak istenilen kavramlar ve beceriler planlı bir şekilde STEM uygulamaları içerisinde kullanarak verilebilir. Okul öncesi dönemdeki çocukların keşfetme-araştırma ruhları ileri seviyededir ve etraflarında gerçekleşen olaylara, nesnelere karşı oldukça meraklı bir yapıya sahiptirler. Planlanan oyun üzerinde çocuğun soru sorma ve hipotez oluşturmalarına imkân verilerek STEM alanlarına yönelik bilgi ve becerileri geliştirilebilir (Uyanık Balat ve Günşen, 2017). Tam da bu noktada Montessori yaklaşımıyla birleştirilmiş STEM etkinlikleri, çocuğa önceden planlanan kazanımlar doğrultusunda hazırlanmış bir çevrede çocuğun özgürce oyun oynamasına ve günlük yaşam becerileri kazanmasına, sorumluluk bilinci oluşturmasına, zihinsel ve bedensel becerileri geliştirmesine yardımcı olmaktadır (Uyanık Balat ve Günşen, 2017). “STEM eğitiminin okul öncesi dönemde uygulatılan ve ortak amaçları barındıran Montessori yaklaşımıyla birlikte hazırlanmış bir öğretme-öğrenme ortamında, etkili şekilde sunulabileceği düşünülmektedir. Bu konuda yeterli araştırma bulunmaması bu konu üzerine odaklanmayı gerekli kılmıştır (Çakır, 2018). Montessori yaklaşımı, İtalyan kadın doktoru Maria Montessori tarafından özgür eğitim anlayışı temel alınarak geliştirilmiş bir eğitim yaklaşımıdır. Dünyada birçok ülkenin okul öncesi eğitim programlarında uygulatılan fakat ülkemizde çalışmalarına henüz yeni başlanan, çocuğun bilişsel, sosyal ve psikomotor beceri gelişiminde olumlu yönde etki eden bir eğitim yaklaşımıdır (Eratay, 2009; Yıldırım Doğru, 2009).

Montessori yaklaşımındaki amaçlar öncelikle çocuğu bir yetişkin yardımı olmadan kendi bireysel beceri ve ihtiyaçlarını karşılayabilecek seviyeye getirmektir. Ayrıca kendi problemlerini çözebilen, sorumluluk bilincine sahip, üretken, kendine ve başkalarına saygılı, yaratıcı ve özgüven sahibi bireyler yetiştirmektir. Bu yaklaşım eğitimin doğal bir süreç olduğunu ve çocuğun kendi iç sesini dinleyerek davranışlarını nasıl yöneteceğini öğreneceğini böylece kendi denetimini sağlayabilen kalıcı bir öğrenim gerçekleştirebileceğini savunur (Yıldırım Doğru, 2009). STEM eğitiminin de amaçları arasında bulu- 
nan, üretken, problem çözebilen, problemi kurabilen, yaratıcılık becerisi gelişmiş, probleme farklı açılardan yaklaşabilen, matematiksel düşünme becerileri gelişmiş bireyler yetiştirmek Montessori yaklaşımının amaçları ile benzerlik göstermektedir. Bunlar göz önüne alınarak doğal bir eğitim ortamında kalıcı öğrenmeyi esas alan Montessori yaklaşımının, disiplinler arası bütünleşik bir öğrenme olan STEM eğitimi için eğitim ortamını zenginleştiren etkili bir öğretim yaklaşımı olduğu söylenebilir (Elkin, Sullivan ve Bers, 2014). Bu kapsamda, eğitim sistemlerinde ihtiyaçlar doğrultusunda eğitim yaklaşımları değişirken, bu alanlarda önce öğretmenlerin yeterli seviyede bilgi sahibi olmaları gerekmektedir. Bunun için özellikle okul öncesi öğretmen adaylarının Montessori ile STEM alanlarında güçlü bir içerik ve pedagojik bilgiye sahip olmaları ve gelecek meslek hayatlarında bu alanları birbiri ile entegre edebilen birer uzman olarak yetiştirilmesi oldukça önemlidir (Çakır ve Altun Yalçın, 2020).

Çalışmanın amacı, Montessori yaklaşımı temelli STEM etkinliklerinin okul öncesi öğretmen adaylarının fene ve fen öğretimine yönelik tutumları üzerindeki olası etkilerini tespit etmektir.. Ayrıca adayların Montessori ve STEM eğitimine yönelik görüşlerini tespit etmek araştırmanın diğer bir amacidır.

\section{Yöntem}

\section{Araştırmanın Deseni}

Çalışmada etkisi incelenen eğitimin etkililiğini birçok kanttla desteklemek amacıyla karma yöntem kullanılmıştır. Karma yöntemin temelinde nicel ve nitel verilerin toplanarak birleştirilmesi ve ilişkilendirilmesi söz konusudur. Böylece araştırmacılar araştırma problemini daha iyi anlamayarak boylamsal bir araştırma yürütmüş olacaklardır (Creswell ve Tashakkori, 2007). Araştırmada ilk önce nicel veriler toplanarak analizleri yapılmıştır. Daha sonra ise elde edilen nicel sonuçları tamamlamak ve desteklemek amacıyla nitel veriler toplanıp analiz edilmiştir (Creswell, 2002). Nicel araştırmanın baskın olması nedeniyle çalışmada karma yöntem çeşitlerinden olan açıklayıcı karma araştırma deseni kullanılmıştır. Açılayıcı karma araştırma desenlerinde nicel araştırmanın baskın olması nedeniyle araştırmacı ilk önce nicel verileri toplar, sonra bu verileri desteklemek ve tamamlamak amaciyla nitel veriler toplanır 
ve analizleri yapılır (Büyüköztürk, Kılıç Çakmak, Akgün, Karadeniz ve Demirel, 2016). Nicel verilerin elde edilmesinde tek grup öntest son test deseni oluşturulmuştur. Çalışma sonunda oluşturulan grup içerisinden gönüllü seçilen 15 kişiye verilen eğitim hakkında görüşme formları uygulanarak nitel veriler elde edilmiştir.

\section{Örneklem}

Çalışmanın örneklemini, Doğu Anadolu' nun orta ölçekli bir ilinin devlet üniversitesinde 3. sinıfta öğrenim gören toplamda 50 okul öncesi öğretmen adayı oluşturmaktadır.

\section{Verilerin Toplanması}

Okul öncesi öğretmen adaylarının fen öğretimine yönelik tutumlarını ölçmek için, Thompson ve Shrigley (1986) tarafından ilköğretim öğretmenlerine yönelik geliştirilen, Cho, Kim ve Choi (2003) tarafından okul öncesi öğretmen adaylarına düzenlenen "Fen Öğretimine Yönelik Tutumları Ölçeği” kullanılmıştır. Ölçek Çamlıbel Çakmak (2006) tarafından Türkçe' ye uyarlanarak Cronbach alpha güvenirlik katsayısı $\alpha=.81$ bulunmuştur. Ölçek 5'li likertli ve 3 maddesi olumsuz olmak üzere toplamda 17 maddeden oluşmaktadır.

Fene yönelik tutumlarını ölçmek için ise Geban, Ertepınar, Yılmaz, Altın ve Şahbaz (1994) tarafından geliştirilen "Fen Bilgisi Tutum Ölçeği" kullanılmıştır. Ölçek $5^{\prime}$ li likert tipi ve 10 olumlu 5 olumsuz madde olmak üzere toplam 15 maddeden oluşmaktadır. Cronbach alpha güvenirlik katsayısı $\alpha=.83$ olarak bulunmuştur.

Yarı yapılandırılmış mülakat formu ise 9 açık uçlu sorudan oluşmaktadır. Bu sorular kullanılan ölçeklerin maddelerine paralel olarak hazırlanmış ve amacına uygunluğu eğitim bilimleri alanındaki iki uzmana inceletildikten sonra onaylatılarak adaylara uygulanmıştır.

\section{Veri Analizleri}

Çalışmada elde edilen nicel veriler istatistiksel analizlere tabi tutulmuştur. Bu analizler için önce verilerin normalliği test edilmiştir. Normallik için örneklem sayısının 30 üzerinde olması sebebiyle Kolmogorov-Smirnov testi dikkate alınarak p anlamlılık değerinin $0,05^{\prime}$ ten büyük çıkması ile verilerin nor- 
mal dağılım gösterdiği tespit edilmiştir (Can, 2016). Daha sonra verilen eğitimin etkililiğini ölçmek için uygulanan ön test ve son test puanları arasında anlamlılık derecesine bakılmıştır. Puanlar arasında bir farklılık gözlenip gözlenmediğini belirlemek amacıyla ilişkili örneklem t-testi yapılmıştır. İlişkili örneklem t-testinde aynı örneklem grubu üzerinde ölçülen ön ve son test puan ortalamaları karşılaştırılmaktadır (Can, 2016).

Nitel verilere ise içerik analizi uygulanmıştır. Bu analiz için önce araştırmacı tarafından yapılan görüşmeler bir araya toplanarak kod ve kategoriler oluşturulur. İçerik analizinde aşamalar sırasıyla verilerin kodlanması, kategorilerin bulunması, kodların ve temaların düzenlenmesi-tanımlanması, bulguların yorumlanması şeklinde tamamlanmaktadır (Yıldırım ve Şimşek, 2008). Yapılan görüşme verileri bir kayıt altına alınarak veriler yazıya dönüştürülmüş ve içerik analizinin aşamalarına uygun olarak analiz edilmiştir. Veri analizlerinin geçerlik ve güvenirlik kısmında oluşturulan kod ve kategoriler 4 ayrı uzmana sunulmuş ve sonuçlar birleştirilmiştir. Nitel veri analiz güvenirlik değeri \%75 bulunmuştur. Kodlayıcılar arası güvenilirlik değeri \%70 üstü ve \% 80'e yakın olması güvenilir olduğunu gösterir (Arastaman, Öztürk Fidan ve Fidan, 2018).

\section{Etik Bilgileri}

Erzincan Üniversitesi İnsan Hakları Etik Kurulu 30.11.2017 tarihli 09/09 sayılı bir çalışmadır. Araştırmada örneklem grubundan veri toplamak üzere seçilen gönüllü bireyler onay formu imzalanarak konu hakkında bilgilendirilmiştir. Bilimsel Araştırma ve Yayın Etiği ile ilgili herhangi bir işlem yapılmamış ve Yükseköğretim Kurumları Bilimsel Araştırma ve Yayın Etiği Yönergesindeki tüm kurallara uyulmuştur.

\section{Süreç}

Çalışmada Montessori yaklaşım temelli STEM etkinlikleri seçiminde bazı özelliklere dikkat edilmiştir. Bunlar; etkinliklerin STEM eğitimi özelliklerini ve Montessori yaklaşımı felsefesini içermesi, öğretmen adaylarının alan bilgilerini kullanarak yeni tasarımlar oluşturabilecekleri heyecanı verebilecek düzeyi içermesidir. Ayrıca adayların etkinliklerde karşılaşacakları problemleri bir önceki yaptıkları etkinlikten edindikleri tecrübe ve bilgileri ile çözebi- 
lecekleri nitelikte olması, meslek hayatlarındaki öğretme ortamlarında ve bireysel gelişimlerinde kullanabilecek düzeyde olmasına önem verilmiştir. Etkinlikler; günlük yaşamın her alanında bulunabilen basit malzemelerden (pet şişe-bardak ve kapakları, pipet, karton kutular, yalıtan kablolar, teneke kutu gibi), robotik-kodlama legolarından, web 2 araçlarından (kahoot, scratch, code.org, tinkercad vb.) ve tiplerden (nişasta ve gıda boyalarıyla renklendirilerek yapılan, sağlık açısından güvenilir, silindir şeklinde küçük süngerlerdir. Islatılan özel bezlerinin üzerine dokundurularak istenilen tasarım şekillendirilmektedir) oluşturulmuştur. Haftada 2 ders saati olmak üzere toplamda 14 hafta süren Montessori yaklaşım temelli STEM uygulamaları bizzat araştırmacıların rehberliğinde okul öncesi öğretmen adaylarıyla gerçekleştirilmiştir. Bu süreçte, adayların fen konularına yönelik tutumlarının olumlu yönde değişmesine ve fen konuları öğretebilme konusunda yeterliliğe sahip olmalarına yardımcı olmaya çalışılmıştır. Bunun yanı sıra fenle ilgili karşılaştıkları bir problemin çözümüne yönelik ön yargılarını kaldırmak, yaratıcılık becerilerini geliştirmek farklı bakış açıları kazanmalarına, öğrendikleri bilgiler ile günlük yaşam durumları arasında bağ kurabilmelerine ve kendi ürünlerini tasarlayabilmelerinin verdiği özgüveni sağlamaya yardımcı olmaya çalışımıştır. Bu uygulamalara geçmeden önce adaylara STEM eğitimi ve Montessori yaklaşımı hakkında temel teorik bilgiler verilmiştir. Daha sonra uzmanlar tarafından belirlenen etkinlikleri yapmak için dört kişiyi geçmeyen gruplar oluşturulmuştur. Sonra haftanın etkinliği hakkında adaylara nasıl yapacakları hakkında teorik bilgiler (gerekli olan fen ve matematik gibi bilgiler, yapılacak etkinliğin çizimle görselleşitirilmesi gibi) anlatılarak gerekli malzemeler tanıtılmıştır. Her grup yapılacak etkinlik için hazırlanan mevcut malzemelerden almaları ve belirlenen 2 saatlik ders sürede etkinliklerini tamamlamaları istenilmiştir. Etkinlik gruplandırılması sırasıyla ilk olarak basit malzemeleri içeren etkinlikler yaptırılmış daha sonrada robotik kodlama, tip çalışmaları ve web 2 araçları uygulatılmıştır. Son olarakda her grup Montessori yaklaşım temelli STEM etkinliklerine uygun olacak şekilde kendi belirledikleri bir konu ve kazanımlar doğrultusunda üzerinde gerekli materyalleri ve etkinlikleri uzmanlardan bağımsız olarak kendileri oluşturup sunmaları istenilmiştir. 


\section{Bulgular}

Çalışmadaki nicel ve nitel bulgular aşağıda tablo ve yorumları ile birlikte verilmiştir.

Tablo 1. Fen öğretimine yönelik tutumlara ilişkin paired samples t-testi sonuçlarn

\begin{tabular}{lllllll}
\hline Ölçümler & $\mathbf{N}$ & $\overline{\boldsymbol{X}}$ & ss & $\mathbf{t}$ & sd & $\mathbf{p}$ \\
\hline Öntest & 50 & 50,54 & 12,40 & $-7,316$ & 49 & \multirow{2}{*}{000} \\
Sontest & 50 & 63,26 & 7,65 & & & \\
\hline
\end{tabular}

Montessori yaklaşımı temelli STEM etkinliklerinin okul öncesi öğretmen adaylarının fen öğretimine yönelik tutumlarına etkisini belirlemek amacıyla ön ve son test puanları arasında yapılan ilişkili örneklemler t-test sonuçları Tablo 1' de gösterilmiştir. Testin sonuçlarında uygulama öncesi puan ortalaması $\left(X_{\text {öntest }}=50.54\right)$ ile uygulama sonrası yapılan puan ortalaması $\left(X_{\text {sontest }}=\right.$ 63.26) arasında anlamlı bir fark görülmüştür $\left(\mathrm{t}_{(49)}=-7,316\right.$; $\left.\mathrm{p}<0.05\right)$. Anlamlılık (p) değerinin 0.05 den küçük olması sonuçların anlamlı farkı sağladığını ifade etmektedir. Bu anlamlı fark sayesinde verilen eğitimlerin okul öncesi öğretmen adaylarının fen öğretimine yönelik tutumlarında olumlu yönde gelişmeler sağladığı söylenebilir.

Tablo 2. Fene yönelik tutumlara ilişkin paired samples t-testi sonuçları

\begin{tabular}{lllllll}
\hline Ölçümler & $\mathbf{N}$ & $\overline{\boldsymbol{X}}$ & ss & $\mathbf{t}$ & sd & $\mathbf{p}$ \\
\hline Öntest & 50 & 45,58 & 4,94 & & & \\
Sontest & 50 & 49,42 & 5,04 & $-3,951$ & 49 &, 000 \\
\hline
\end{tabular}

Montessori yaklaşımı temelli STEM etkinliklerinin okul öncesi öğretmen adaylarının fene yönelik tutumlarına etkisini belirlemek amacıyla ön ve son test puanları arasında yapılan ilişkili örneklemler t-test sonuçları Tablo 2’ de gösterilmiştir. Testin sonuçlarında uygulama öncesi puan ortalaması $\left(\overline{\boldsymbol{X}}_{\text {Öntest }}\right.$ $=45,58)$ ile uygulama sonrasi puan ortalamasi $\left(\overline{\boldsymbol{X}}_{\text {Sontest }}=49,42\right)$ arasinda anlamlı bir fark görülmüş̧ür $(\mathrm{t}(49)=-3,951, \mathrm{p}<0.05)$. Bu anlamlı fark sayesinde verilen eğitimlerin okul öncesi öğretmen adaylarının fene yönelik tutumlarında olumlu yönde gelişmeler sağladığı söylenebilir. 
Aşağıda nitel verilerin analizleri yapılarak her sorunun tablosuna ve yorumuna yer verilmiştir.

Tablo 3. "Etkinlikler sizin fen dersine yönelik tutumunuza karşı bir etkisi oldu mu?" sorusuna ilişkin öğretmen adaylan görüşleri

\begin{tabular}{lll}
\hline Kategori & Kod Adı & Frekans $(\mathbf{f})$ \\
\hline & Eğlence & 8 \\
& Yaparak-yaşayarak & 4 \\
Öğrenme & Kalıc & 1 \\
& Farklı boyutlar & 2 \\
& Gözlemleme & 1 \\
& Fen & 1 \\
\hline & Somutlaştırma & 1 \\
Etki-Katkı & Avantajları & 7 \\
& Bakışaçısı & 1 \\
\hline Toplam & Feni sevme & 9 \\
\hline
\end{tabular}

Tablo 3' te soruya ilişkin öğretmen adaylarının cevaplarına yer verilmiş ve 2 ayrı kategori oluşturulmuştur. Öğrenme kategorisi; okul öncesi öğretmen adayları yapılan etkinliklerin fene yönelik tutumlarında öğrenme üzerinde olumlu etkiler bıraktı̆ını belirtmişlerdir. Etkinlikleri birebir kendileri yaptıkları için kalıcı bir öğrenim olduğunu, zor görünen fen konularını deneyler yaparak, değişik etkinlikler üzerinde görerek çok kolayca öğrendiklerini, grupça yapılmasında diğer arkadaşların yaptıklarını gözlemler yaparak öğrenmeler sağladıklarını, olaya ya da soruna farklı boyutlarda bakabilmeyi öğrendiklerini ve dersleri sıkılmadan eğlenerek geçirdiklerini belirtmişlerdir.

Etki-katkı kategorisinde; adayların verilen eğitim sonunda fene karşı oluşan olumlu etkilerden ve katkılardan bahsedilmiştir. Fen konularının zor olmadığını aksine zevkli ve eğlenceli yanlarını bu eğitimle keşfettiklerini, anlaşılmaz gördükleri soyut konuları bu etkinliklerle somutlaştırdıklarını, günlük yaşamlarında da avantajlar sağladığını yani çevreyi fenle ilişkilendirmeye başladıklarını belirtmişlerdir. Ek olarak fen dersini küçüklükten beri hiç sevmeyen bireylerin bu etkinlikler sayesinde sevmeye başladıklarını, feni sevenlere ise daha da sevdirdiğini ve fenle ilgili durumlarda, farklı açılardan bakabilme yeteneklerinin geliştikleri belirtmişlerdir.

Aşağıda bazı öğretmen adaylarının görüşlerine yer verilmiştir.

- "Liseden beri feni zor buluyordum, anlamiyordum ve yapamyordum. Ama bu etkinliklerde fenin zor olmadığını, çok eğlenceli bir ders olduğınu gördüm. Ve fenden zevk aldım. Önceden hiç sevmezdim.." 
- "Aslında fenin kağıt üzerinde zor, uygulamaya geçince ise o kadar da zor olmadı̆̆ını gördüm.."

- "Fende bize öğrettikleri bi elektirk devresi ve bide bikaç kuvvet uygulamasiydl. Ve bu etkinliklerde bize öğretilenlerden fenin çok farklı boyutlarını öğrendik. Fene yönelik artık olumlu etki oluşturdu.."

Tablo 4. "Etkinliklerin fene yönelik tutum ve davranşlarmizı olumlu ya da olumsuz olarak değiştirdiğini dïşünüyor musunuz?" sorusuna ilişkin öğretmen adaylarn görüşleri

\begin{tabular}{lll}
\hline Kategori & Kod Adı & Frekans(F) \\
\hline & Olumlu etki & 8 \\
Tutum- Davranış & Feni eleştirme & 1 \\
& Soyutlanma & 1 \\
& Ön yargı & 1 \\
& Somutlaştırma & 2 \\
\hline Toplam & & 22 \\
\hline
\end{tabular}

Tablo 4' te soruya ilişkin öğretmen adaylarının cevaplarına yer verilmiş ve tek kategori oluşturulmuştur. Tutum- davranış kategorisinde; okul öncesi öğretmen adayları etkinliklerden sonra fene yönelik olumlu tutum ve düşüncelerinin oluştuğunu belirtmişlerdir. Bunlar, feni bu eğitimden önce hiç sevmediklerini, oldukça zor bir ders olarak düşündüklerini ve bu eğitimden sonra fenin çok eğlenceli bir ders olduğunu, etkinlikleri yaparken zevk aldıklarını, soyut konuların kolayca somutlaştırılarak akılda kalıcılığını sağlandığını ayrıca artık fen konularını eleştirebilme, yorumlar yürütebilme gibi bilgi ve yeteneklerinin geliştiğini belirtmişlerdir.

Aşağıda bazı öğretmen adaylarının görüşlerine yer verilmiştir.

- "Kesnlikle değgiştirdi. Olumlu yönde etkiledi. En önemlisi fene olan ön yargımı kırdı. Kolay olduğunu, yapabildiğimi gösterdi. Konular somutlaştırarak daha kolay öğrenmemizi sağladı..."

- "Olumlu yönde bir etkisi oldu. Fenle ilgili bişey bilmezken artık fe konuları hakkında yorum yapabiliyor hatta farklı bakışla açlarıyla eleştirebiliyorum..." 
Tablo 5. "Etkinliklerden sonra çevrende fene yönelik güncel bilgi ya da kitap tarzı şeyler ilginizi çekmeye başladı mı? Nasıl?" sorusuna ilişkin öğretmen adayları görüşleri

\begin{tabular}{lll}
\hline Kategori & Kod Adı & Frekans(F) \\
\hline \multirow{4}{*}{ Güncellik } & Haberler & 4 \\
& Kitaplar & 1 \\
& TV programları & 1 \\
& Fen konuları & 1 \\
\hline \multirow{3}{*}{ Alg1 } & Dikkat çekme & 11 \\
& Yönelme & 2 \\
& Eğlenceli bulma & 2 \\
& Yanlışlar düzeltme & 1 \\
\multirow{2}{*}{ Ilgi } & Seçicilik & 2 \\
\hline Toplam & Kullanma isteği & 1 \\
& Araşırıa isteği & 1 \\
\hline
\end{tabular}

Tablo $5^{\prime}$ te soruya ilişkin öğretmen adaylarının cevaplarına yer verilmiş ve üç kategori oluşturulmuştur. Güncellik kategorisinde; öğretmen adayları etkinliklerden sonra çevresinde fenle ilgili konulara yönelik haberlere, televizyon programlarına ve kitaplara dikkatlerinin arttı̆̆ını belirtmişlerdir.

Alg1 kategorisinde; adaylar etkinlikler sonrasında çevrelerinde fene yönelik algılarında oluşan değişimleri belirtmişlerdir. Adaylar etkinliklerden sonra çevrelerinde fene yönelik algıda seçicilik düzeylerinin ve dikkatlerinin arttığını, fen konularında yanlış bildikleri bilgileri düzeltmeye başladıklarını, feni çok sıkıcı görme gibi ön yargılarının yok olduğunu ve artık feni çok eğlenceli bulduklarını belirtmişlerdir.

İlgi kategorisinde; adaylar fene olan ilgilerinin arttı̆̆ını, kendi derslerine fen konularını katmak istediklerini, fen ile ilgili araştırma-inceleme yapmaya başladıklarını, çevrelerinde fenle ilgili olaylara dikkatlerinin arttığını belirtmişlerdir.

Aşağıda bazı öğretmen adaylarının görüşlerine yer verilmiştir.

- "Evet. Mesela geçen haberlerde fenle ilgili yapilan projeler vardı. Bide stemle yapıldı̆̆ın söyleyince daha çok dikkatle izledim. Ne yapmış nasıl yapmış neler kullanmış diye. Feni daha çok kullanma duygusu gelişti. Staj yaparken fenle ilgili şeyler yapmak istiyorum ..."

- "Tabiki. Mesela dün haberde izledim. Kardeşi arabada kilitli kaldığı için vefat eden biri bu durumdan sonar bir çözüm üretmiş. Araba kilitlendiğinde içerde fen konusunu barnndıran bi düzenek krmuş ve basinca alarm veriyor. Ve bunun fenle ilgili olması beni habere daha çok odaklanmamı sağladı..." 
Tablo 6. "Etkinlikler sizin feni günlük yaşamla birleştirip anlamlandırmanıza herhangi bir katkısı oldu mu?" sorusuna ilişkin öğretmen adayları görüşleri

\begin{tabular}{lll}
\hline Kategori & Kod Adı & Frekans(F) \\
\hline \multirow{3}{*}{ Öğrenme } & Kalıcı & 4 \\
& Güncel & 4 \\
& Fen konuları & 5 \\
\hline \multirow{2}{*}{ Katkı } & Tahmin yürütme & 1 \\
\hline Toplam & Hayatla birleştirme & 7 \\
\hline
\end{tabular}

Tablo 6' da soruya ilişkin öğretmen adaylarının cevaplarına yer verilmiş ve iki kategori oluşturulmuştur. Öğrenme kategorisinde; adaylar etkinlikler sonrasında fen konularında kalıcı öğrenmeler gerçekleştirdiklerini, feni hayatlarındaki güncel olaylarla birleştirerek öğrendiklerini ve var olan bir konu hakkında farklı tahmin yürütme yolları öğrendiklerini belirtmişlerdir.

Katkı kategorisinde; öğrenme kategorisine benzer olarak adaylar fen konularını günlük yaşamlarında artık daha kolay anlamlandırabildiklerini belirtmişlerdir. Etraflarında bulunan lunaparklardaki makineler, evlerindeki elektrikle çalışan makineler gibi araçların nasıl çalıştıklarını ve feni bu alanlarda nasıl kullandıklarını anlamlandırdıklarını, fene yönelik ilgi-tutumlarının arttığını, evlerinde ya da diğer yaşamlarında feni kullanmaya başladıklarını ve çevrelerinde daha dikkatle baktıklarını belirtmişlerdir.

Aşağıda bazı öğretmen adaylarının görüşlerine yer verilmiştir.

- "Fenle ilgili çok bilgim yok. Liseden beri seomem. Ama bu etkinliklerde feni sevdim mesela trafik lambasının fenle ilgili olduğunu bu etkinliklerle öğrendim. Fenin formülden ibaret olmadığını gördüm..."

- "Tabiki. Mesela günlük yaşamda çalı̧an o robotların, makinelerin falan arkasinda bir bilgisayar yardımı ile çalıstığııı daha iyi anlamlandırdım..."

Tablo 7. "Etkinlikler fen konularnı öğrenmenize ve bu konuları daha iyi öğretebilmenize yardımcı oldu mu? Bu konuda geliştiğinizi düşünüyor musunuz?" sorusuna ilişkin öğretmen adaylarn görüşleri

\begin{tabular}{lll}
\hline Kategori & Kod Adı & Frekans(F) \\
\hline & Eğlenme & 6 \\
& Gözlemleme & 1 \\
Öğretme- Öğrenme & Bilgi & 2 \\
& Basite indirgeme & 1 \\
& Geri dönüşüm & 1 \\
& Dönüp düzeltmeler & 1 \\
\hline \multirow{2}{*}{ Katkı sağlama } & Fen öğrenme & 12 \\
& Teknolojik aletler & 3 \\
\hline
\end{tabular}




\begin{tabular}{lll}
\hline & İnanç & 1 \\
& Yetenek & 3 \\
& Feni ögretebilme & 16 \\
\hline \multirow{2}{*}{ Ilgi } & Merak duyma & 3 \\
& Eğlenceli bulma & 1 \\
\hline Toplam & & 51 \\
\hline
\end{tabular}

Tablo $7^{\prime}$ de soruya ilişkin öğretmen adaylarının cevaplarına yer verilmiş ve 3 kategori oluşturulmuştur. Öğrenme-öğretme kategorisi; adaylar yapılan etkinliklerin fen konularını öğrenme ve öğretmelerine oldukça yardımcı olduğunu belirtmişlerdir. Fen konularını öğrenmekten zevk aldıklarını, birebir uygulama yaptıkları için konuları aşamalar halinde gözlemleyerek öğrenme fırsatı bulduklarını, zor sanılan fen konularını basite indirgeyerek çocuklara kolaylıkla öğretebileceklerini, uygulamalar sırasında sahip olunan yanlış bilgileri düzeltme imkânı bulduklarını, etkinliklerde yaptıkları hataları fark edebilmelerine ve dönüp düzeltmeler yapmalarına fırsat verdiğini belirtmişlerdir. Ayrıca çocuklara eğlenceli ders ortamı oluşturarak fen konularını öğretebileceklerini ve çevrelerindeki atık malzemeleri etkili bir şekilde geri dönüşümle değerlendirebilmeyi öğrendiklerini belirtmişlerdir.

Katkı sağlama kategorisinde; adaylar farklı bir alan olan fen alanında birçok konu öğrendiklerini ve meslek hayatlarında bu öğrendiklerini, öğretebilecek yeterlilik ve inançlarının oluştuğunu, birçok teknolojik aletlerin nasıl kullanıldığını bu eğitimlerle öğrendiklerini belirtmişlerdir.

İlgi kategorisinde; adaylar fen dersine karşı merak duymaya başladıklarını ve öğrendikleri konuları meslek hayatlarında çocukların düzeylerine indirerek onlarında küçük yaşlarda fene merak uyandırmaları sağlayacaklarını, araştırma-sorgulama becerilerini geliştirebileceklerini ve feni eğlendirerek öğretebileceklerini belirtmişlerdir.

Aşağıda bazı öğretmen adaylarının görüşlerine yer verilmiştir.

- “Feni öğrenmeme katkı sağladr. Teknolojik aletlerin nasıl yapıldığın öğretti...Fenin tamamın değil ama yarıdan fazlasın öğretebileceğimi düşünüyorum..."

- "Okul öncesine yetecek kadar, çocukları fene yönelik meraklarını uyandıracak kadar fen öğrendiğimi ve bunları öğretebileceğimi düşünüyorum..."

- "Aslında feni keendimiz zorlaştırıyoruz. Aldığımı eğitim sayesinde feni güzel bir şekilde öğretip kolay şekilde yansitabileceğimi düşünüyorum.." 
Tablo 8. "Etkinlikler sizin meslek hayatınızda feni öğretme isteğinize ya da fen etkinlikleri yaptırmak istemenize karşı bir katkısı oldu mu? Neden?" sorusuna ilişkin öğretmen adaylarn görüşleri

\begin{tabular}{lll}
\hline Kategori & Kod Adı & Frekans(F) \\
\hline \multirow{2}{*}{ Uygulama } & Somutlaştırma & 6 \\
& Dikkat çekme & 1 \\
\hline & Ön yargı & 3 \\
& Merak & 1 \\
& Yaratıcllı & 2 \\
Feni Öğretme İsteği & Özgüven & 2 \\
& Başarı & 1 \\
& Feni doğayla birleştirme & 1 \\
& Eğlenceli ders & 1 \\
\hline Diğer & Tasarım & 2 \\
\hline Toplam & Materyal biriktirme & 1 \\
\hline
\end{tabular}

Tablo 8' de soruya ilişkin öğretmen adaylarının cevaplarına yer verilmiş ve üç kategori oluşturulmuştur. Uygulama kategorisinde; adaylar etkinliklerin meslek hayatlarında feni öğretme istekleri üzerinde olumlu etkiler bıraktığını belirtmişlerdir. Bunun nedeni olarak uygulanabilirlik açısından kolay olduğunu, fen konularının bu etkinlikler sayesinde elle tutulabilir (somutlaştırma), görülebilir bir hale getirdiğini, basit ve eğlenceli olması nedeniyle çocuğun seviyesine uygun olduğunu ve dikkatlerini kolayca derse çekebilecek düzeyde olduğunu belirtmişlerdir.

Feni öğretme isteği kategorisinde; adaylar fene yönelik öğretme isteklerinin verilen eğitimle arttığını söylemişlerdir. Çocuğa küçük yaşlarında temelden fene yönelik bir merak oluşturmak, ortaya çıkarılan ürün ile elde edilen başarı duygusunu tattırarak özgüveni oluşturmak, feni sevdirmek, fene karşı bir ön yargılarının oluşmasını engellemek, çocuğun yaratıcılık becerilerini açığa çıkarmaya yardımcı amacıyla meslek hayatlarında feni öğretmek istediklerini belirtmiştir. Ayrıca feni doğayla bütünleştirerek dersleri eğlenceli kılmayı ve olumlu sonuçlara ulaşmayı istediklerini belirtmişlerdir.

Diğer kategorisinde ise etkinliklerinden sonra bir öğretmen adayının öğrencileri için şimdiden birçok materyal biriktirmeye başladığını belirtmiştir.

Aşağıda bazı öğretmen adaylarının görüşlerine yer verilmiştir.

- "Tabiki. Çünkü zaten bölüm olarak okul öncesi olduğumuz için hep somut şeyler kullanmamiz lazım. Bu etkinliklerde de bütün materyaller somut olduğu için baya baya katkı sağladı bize.." 
- "Tabiki katkı sağladı. Hatta şimdiden ileri meslek hayatım için evde şişe kapağı, kablo vb. materyaller bile biriktirmeye başladım, o derece yani.."

Tablo 9. "Montessori Yaklaşımına yönelik en beğendiğiniz özellikleri nelerdir?" sorusuna ilişkin öğretmen adaylan görüşleri

\begin{tabular}{lll}
\hline Kategori & Kod Adı & Frekans(F) \\
\hline \multirow{3}{*}{ Ahlaki Değerler } & Sorumluluk bilinci & 4 \\
& Paylaşımclık & 8 \\
& Saygı duyma & 12 \\
\hline \multirow{3}{*}{ Öğrenme } & Yaparak yaşayarak & 5 \\
& Oyun oynayarak & 1 \\
& Dokunarak & 1 \\
& Görerek & 1 \\
\hline \multirow{4}{*}{ Bilimsel Davranışlar } & Yaratıılık & 7 \\
& Problem çözme & 5 \\
& Çözüm üretme & 3 \\
& Bireysel beceriler & 1 \\
& İtiyaçlar & 1 \\
& Özgüven & 2 \\
\hline \multirow{3}{*}{ Eğitsel Kazanımlar } & Hayata hazırlama & 1 \\
& Üretmeye firsat sunma & 1 \\
& Birebir etkinlik yapma & 7 \\
\hline \multirow{3}{*}{ Materyal özellikler } & Boyut & 1 \\
& Eğitsel & 1 \\
& Matematiksel & 1 \\
& Ahşap & 1 \\
& Geri dönüşüm & 1 \\
\hline Toplam & Doğal & 1 \\
\hline
\end{tabular}

Tablo $9^{\prime}$ da soruya ilişkin öğretmen adaylarının cevaplarına yer verilmiş ve 5 kategori oluşturulmuştur. Ahlaki değerler kategorisinde; adaylar Montessori yaklaşımının çocuğa sunduğu özgürce seçimleri yani her işini kendi yapmasına fırsat vermesi, kendine ve başkalarına karşı saygı ve sorumluluk duygusu kazandırması önemli bir özelliği olduğunu vurgulamışlardır. Ayrıca Montessori materyallerinin tek sayıda olması çocuğun o an yapmak istediği materyalle başka arkadaşı oynuyorsa oyununu bitirmesini beklemesini ya da birlikte oynamasına olanak sağladığını böylece çocuğa yardımlaşma, paylaşma, sırasını bekleme gibi davranışları öğrettiğini belirtmişlerdir.

Öğrenme kategorisinde; adaylar Montessori yaklaşımının, öğretilecek bilgiyi çocuğa oyun oynatarak kazandırdığını, çocuğa belirlenen bir çerçeve içerisinde öğrenme özgürlüğü sunması yani kendi yapmak istediğine fırsat 
vermesi, öğretilmek istenilen dil gelişimi, matematik vb. konuların Montessori yaklaşımı materyalleri ile dokunarak ve görerek daha kolay öğretilmesine yardımcı olduğunu belirtmişlerdir.

Bilimsel davranışlar kategorisinde; adaylar Montessori eğitiminin çocuğun problem çözme ve yaratıcllık becerilerini geliştirdiğini, ortaya çıkan bir sorun karşısında alternatif çözümler üreten bireyler yetişmesini ve çocukların kendi bireysel ihtiyaçlarını yetişkin yardımı olmadan karşılayabilecek seviyeye getirmede katkı sağladığını belirtmişlerdir.

Eğitsel kazanımlar kategorisinde; yine Montessori eğitiminin beğenilen eğitsel özellikleri hakkında bilgi verilmiştir. Adaylar bu eğitimin çocuğu hayata hazırladığını, her ihtiyacını kendisinin gidermesini sağladığını (kendi yemeğini hazırlayabilme, kendi montunu giyme, kendi sofrasını toplayıp y1kama gibi), çocuğun aktif katılımıyla uygulama yaparak üretmeye fırsat vermesini sağlamasının önemini vurgulamışlardır.

Materyal özellikleri kategorisinde ise; adaylar Montessori materyallerini çok beğendiklerini, eğitsel olarak oldukça kullanışıı bulduklarını belirtmişlerdir. Yine materyaller konusunda masa, sandalye, dolap gibi eşyaların boyutlarının çocuğun boyuna göre olması çocuğa işlerini yaparken kolaylık sağladığını, materyallerin ahşap ve doğal malzemelerden üretilmesinin sağlık açısından da önemli bir özelliği içerdiğini belirtmişlerdir. Matematik içerikli çok çeşitli materyallerinin bulunması ve atık malzemelerin geri dönüşümü ile materyaller üretilebilmesi açısından da beğendiklerini belirtmişlerdir.

Aşağıda bazı öğretmen adaylarının görüşlerine yer verilmiştir.

- "Materyal olarak her nesneden bir tane bulunması çocuğun yardımlaşma ve paylaşma davranışı kazandırmasını să̆laması..."

- "Yaparak yaşayarak çocuğa uygulama firsatı sunması..."

- "Materyallerinin doğal olması, çocuğun kendisi özgürce bişeyler üretmesi..."

- "Çocuğa sorumluluk alma bilincini oluşturmasına katkı sağlama..." 
Tablo 10. “STEM Eğitimine yönelik en beğendiğiniz özellikleri nelerdir?” sorusuna ilişkin öğretmen adaylarn görüşleri

\begin{tabular}{lll}
\hline Kategori & Kod Adı & Frekans(F) \\
\hline \multirow{3}{*}{ Ahlak - Davranış } & Görüsslere saygı & 2 \\
& Pes etmeme & 2 \\
& Özgüven & 2 \\
\hline \multirow{3}{*}{ Bilimsel Davranışlar } & Yaratıcılık & 8 \\
& Problem çözme & 5 \\
& Tahmin yeteneği & 1 \\
& Küçük kas becerisi & 1 \\
& Bakışaçısı & 1 \\
& Ürün & 4 \\
\hline \multirow{2}{*}{ Eğitimsel Özellikler } & Bilgiyi somutlaştırma & 1 \\
& Matematik materyaller & 2 \\
& Yeniliğe açık & 1 \\
\hline \multirow{2}{*}{ Duygu } & Teknoloji & 3 \\
\hline Toplam & Mutlu etmesi & 3 \\
\hline
\end{tabular}

Tablo $10^{\prime}$ da soruya ilişkin öğretmen adaylarının cevaplarına yer verilmiş ve 4 kategori oluşturulmuştur. Ahlak- davranış kategorisinde; eğitimin bireye kazandırdığı ahlaki davranışlardan bahsedilmiştir. STEM eğitiminde etkinlikler grupla yapılması birbirlerinin görüşlerine saygı duyduklarını, etkinlikleri bir dayanışma ve yardımlaşma içerisinde tamamladıklarını, hatalar yapsalar bile sonuca varmak için sorunlar karşısında asla pes etmemeyi öğrendiklerini ve süreç sonunda ortaya bir ürün koymanın özgüvenlerini olumlu yönde etkilediğini belirtmiştir.

Bilimsel davranışlar kategorisinde; adaylar STEM' in en çok beğendikleri özelliğinin bireyin bilimsel süreç beceri ve davranışlarını geliştirdiğini belirtmişlerdir. Yaratıcılığı ve problem çözme becerilerini geliştirdiğini, olaylara farklı açılardan bakabilmeyi öğrettiğini, çocukların küçük kas becerilerinin gelişmesine yardımcı olacağını, yaptığı işlerde hep bir sonraki adımı tahmin etmeyi yani ön görüşlü olmayı öğrettiğini ve ortaya bir ürün koymayı sağladığını belirtmişlerdir.

Eğitimsel özellikleri kategorisinde; STEM eğitiminin, bilgiyi çocuğa somutlaştırarak vermesi öğrenmenin kalıcılı̆̆ını sağlamasını, materyallerinde farklı disiplinleri bir arada bulundurması, yeniliği ve gelişen teknolojiyi içermesi, bireyi mutlaka bir sonuca yönlendirmesi ve ulaştırması açısından önemini belirtmişlerdir. 
Duygu kategorisinde; STEM' in bireye kazandırdığı duygusal özelliklerine yer verilmiştir. Yaptıkları etkinliklerde adaylar ortaya bir ürün çıkarmanın bir şeyler üretmenin haz ve mutluluk verdiğini, oluşan ürünün bazen çok şaşırttı̆̆ını, derste kazandırılmak istenen konunun eğlenceli bir şekilde öğretildiğini belirtmişlerdir.

Aşağıda bazı öğretmen adaylarının görüşlerine yer verilmiştir.

- "Çocuğun küçük kas becerilerini geliştiriyor, yaratıcllğ̆m geliştiriyor. Bir sonraki adımları tahmin edebilmee becerisi kazandırmast.."

- "Problem çözme becerisi kazandırması.Yardımlaşma ve fikirlere saygı duyma davranışlarmı çocuğa öğretmesi.."

- "Yapılan ürünün hareket etmesi, dersi eğlenceli kılması, bir şeyler üretmenin verdiği özgüven duygusu.."

Tablo 11. "Boş zamanlarnızda fenle ilgili bu tarz etkinlikleri yapmak ister misin?" sorusuna ilişkin öğretmen adaylarn görüşleri

\begin{tabular}{lll}
\hline Kategori & Kod Adı & Frekans(F) \\
\hline \multirow{3}{*}{ Faydalar } & Zamanın içine katma & 2 \\
& Üretim & 1 \\
& Çocuklara uygun & 1 \\
\hline \multirow{2}{*}{ Tutum } & Eğlenceli & 5 \\
& İstek & 1 \\
\hline \multirow{3}{*}{ Uygulama } & Deneyler yapma & 1 \\
& Tiplerle çalışma & 1 \\
& Legolarla çalışma & 1 \\
\hline Toplam & Evde yapma & 1 \\
\hline
\end{tabular}

Tablo 11' de soruya ilişkin öğretmen adaylarının cevaplarına yer verilmiş ve 3 kategori oluşturulmuştur. Faydalar kategorisinde; adaylar soruya olumlu cevaplar vererek boş zamanlarını değerlendirme amaçlı, bilime katkı sağlamak ve daha fazla üretim amaçlı, çocuklara yönelik de olduğu için ilerde çocuklarıla vakit geçirmek amaçlı ve bir şeyler tasarlamanın verdiği duyguyu sevmesi sebebiyle direk zamanının içine katarak vakit ayıracağını, bu tarz etkinlikleri yapmak istediklerini belirtmişlerdir.

Tutum kategorisinde; adaylar etkinlikleri çok eğlenceli ve zevkli buldukları için boş zamanlarında bolca yapmak istediklerine belirtmişlerdir.

Uygulama kategorisinde; adaylar boş vakitlerinde etkinliklerde öğrendikleri doğrultusunda hangi tarz etkinlikleri uygulamak istediklerini belirtmişlerdir. Bazıları robotik kodlama legolarını, bazıları tip çalışmasını daha çok 
yapmak istediklerini, bazıları basit malzemelerle evde farklı tasarımlar üretmek istediklerini, bazıları ise deney tarzı etkinlikleri yapmak istediklerini belirtmiştir.

Aşağıda bazı öğretmen adaylarının görüşlerine yer verilmiştir.

- "İsterim yani hatta boş zamanı kullanmak değil direk bunlan zamanımın içerisine katmak isterim..."

- "Bu alanlarla ilgili daha fazla ve çeşitliliği içeren etkinlikler üretip eğitimi katkı sağlamak isterim.."

- "Evet isterim. Özellikler tiplerle yapmay daha çok isterim..."

\section{Tartışma ve Sonuç}

Geleceğin öğretmenleri olarak öğretmen adaylarımızın eğitim ortamlarını, amaçlara uygun ve doğru bir biçimde oluşturmaları gerekmektedir. Bu ortamları sağlayabilmeleri için öncelikle kendi alanları dışındaki farklı disiplinlere yönelik sahip oldukları önyargılardan yani olumsuz düşünce ve tutumlardan arınmış olmaları gerekir (Çevik, Danıştay ve Yağcı, 2017). Ayrıca hizmet öncesi dönemlerinde edindikleri bilgi ve tecrübelerin yeterli ve doğru şekilde edinilmesi oluşacak tutum ve algı açısından önemlidir (Tezel ve Yaman, 2017). Verilen bu bilgiler doğrultusunda yapılan çalışma sonuçlarında Montessori temelli STEM etkinliklerinin okul öncesi öğretmen adaylarının fene ve fen öğretimine karşı tutumlarında olumlu yönde gelişim tespit edilmiştir. Ayrıca eğitim sonunda adaylarla nitel amaçlı yapılan görüşmeler de nicel sonuçları desteklemektedir. Literatüre bakıldığında yapılan çalışmanın yani Montessori ve STEM' in ortak olarak bulunduğu çalışmaların sayısı oldukça azdır ( Açıkgöz, 2018; Çakır, 2018; Çakır, Altun Yalçın ve Yalçın, 2020; Elkin, Sullivan ve Bers, 2014). Çalışmada STEM eğitiminin okul öncesi dönemde Montessori yaklaşımı felsefesi temel alınarak çalışmaların yürütülmesinin elde edilen olumlu sonuçlar doğrultusunda önemi vurgulanmaktadır. Bunu destekler nitelikte Elkin, Sullivan ve Bers (2014), okul öncesi dönemde Montessori sınıflarında robotik müfredatının uygulanmasının nasıl olabileceğini araştırmışlardır. Araştırmanın sonucunda robotik ve mühendislik kavramlarının Montessori okul öncesi sınıflarında uygulamasının etkili bir şekilde nasıl entegre edilebileceğine ilişkin öneriler sunmuşlardır. Araştırmada Montessori ilkelerini teknolojiyle harmanlamanın önemi ve robotların çocukların 
yaratıcılıklarını geliştireceği belirtilmiştir. Robotik uygulamalarının erken çocukluk eğitiminde verilmesi çok yeni bir çalışma olsa da Montessori sınıflarında rahatlıkla uygulanabileceğini belirtmişlerdir. Bu ifadeler yapılan çalışmanın STEM eğitimlerinin okul öncesi dönemdeki Montessori sınıflarında uygulanmaya başlanması gerektiğini belirten bulgularını destekler niteliktedir. Yamak, Dündar ve Bulut (2014), STEM uygulamalarının beşinci sınıf öğrencilerinin fene yönelik tutumlarına etkisini incelemiştir. Sonuç olarak, uygulamaların öğrencilerin fene yönelik tutumları üzerinde olumlu etkiler yarattığ 1 belirlenmiştir. Ricks (2006), bilim kamplarında verilen STEM eğitimlerinin öğrencilerin fene yönelik tutumlarında olumlu yönde etkiler gözlendiğini vurgulamıştır.

Çalışmanın nitel sonuçlarında adayların STEM ve Montessori yaklaşımına yönelik de olumlu tutum ve düşüncelerine ulaşılmıştır. Çalışmayı destekler nitelikte Çalık (2020), fen bilgisi öğretmen adaylarının verilen STEM eğitimlerinden sonra STEM alanlarına yönelik tutumlarda olumlu etki yaptığını belirtmiştir. Bu sonuçlar bu çalışmada elde edilen sonuçları desteklemektedir. Saad (2014) 8. sınıf öğrencileri ile yaptığı STEM çalışmasında öğrencilerin fen dersine karşı tutumlarının olumlu yönde geliştiği tespit etmiştir. Lamb, Akmal ve Petrie (2015) çalışmalarında STEM eğitiminin öğrencilerde fene yönelik tutumu arttırdığı sonucuna ulaşmışlardır. Wyss, Heulskamp ve Siebert (2012) ortaokul seviyesindeki öğrencilerin STEM' e karşı ilgilerini araştırdıkları çalışmada, STEM alanındaki profesyonellerle gerçekleştirilen video kayıtlarının, öğrencilerde STEM' e olumlu tutumu arttırdığı sonucuna ulaşmışlardır. Şahin (2013), öğrencilerin STEM etkinliklerine katılımının, STEM alanlarına karşı olumlu tutumu artırdığını ifade etmiştir.

Çalışmanın nitel sonuçlarında adaylar, fene yönelik ön yargılarının kalktığını artık feni ve teknolojiyi kendi alanları ile entegre edebilecek düzeye geldiklerini, STEM ve Montessori yaklaşımının çocuk için anlamlı öğrenmeler sağlamasında uygun olduğunu bizim eğitim sistemimize koyulmasında bazı eksiklikler yaşanacağını belirtmişlerdir. Bunlar, eğitimler için özel sınıfların olmaması, maddi açıdan malzemelerin temini konusunda sıkıntı olabileceğini ve öğretmenlerin bu eğitimler hakkında yeterli seviyede olmaması tarzı sıkıntıları belirtmişlerdir. Aslan ve Bektaş (2019), çalışma sonuçları destekler nitelikte olan fen bilimleri öğretmen adaylarının STEM uygulamalarına yönelik görüşlerini araştırmıştır. Sonuçlarında adayların fen dersini diğer disiplinle ilişkilendirebildiklerini, ortaokul fen dersi programına STEM' in entegre 
edilmesi gerektiğini ve maddi açıdan belki sıkıntılar olabileceğini içeren görüşleri belirtmişlerdir. Ek olarak öğretmen adayları STEM eğitimi ile anlamlı öğrenmelerin olacağını ve STEM etkinlikleri hakkında ileri düzeyde bilgi sahibi olmaları için hizmet öncesi dönemde verilmesi gerektiğini ve öğretim programlarının STEM uygulamaları ile desteklenmesi gerektiği belirtilmiştir.

Yine nitel sonuçlarda adayların; verilen eğitimle özgüven ve derse karşı motivasyonlarının arttığını, eğitimlerden zevk aldıklarını, bütün grup üyelerinin aktif katılım sağlamasına neden olduğunu, bilimsel becerilerinin geliştiğini, probleme farklı açılardan bakabilmeyi öğrendiklerini, yaparak yaşayarak öğrenme fırsatı sunulması konuyla ilgili kalıcı öğrenmeler sağladıklarını, ortaya ürün koymanın konuyu somuta dökmede çok iyi öğrendiklerini belirtmişlerdir. Sonuçları destekler nitelikte olan başka bir çalışmada Bakırcı ve Kutlu (2018) çalışmalarında fen bilgisi öğretmenlerinin STEM hakkındaki görüşlerini araştırmışlardır. Sonuçlarında, öğretmenler STEM' i öğrencilerin derse yönelik ilgilerini ve motivasyonların artıracağı, karar verme becerilerini geliştireceği ve alternatif düşünme yöntemleri sağlayacağı belirtilmiştir. Ayrıca, STEM eğitimiyle öğrencilerin bilgi edinmede yaparak yaşayarak öğrenmeyi sağlayacağını, yaratıcılık gibi bilimsel süreç becerilerini ve araştırma-sorgulama becerilerini geliştireceklerini, konular somutlaştırarak öğrenmeler sağlanacağını ve problem durumuna uygun ürün tasarlamalarına yardımcı olacağını belirtmişlerdir. Ek olarak sonuçlarında STEM eğitiminde öğretmenlerin yeterli donanımda olmadıklarını da belirtmişlerdir. Çömek ve Avcı (2016), fen eğitiminde robotik kodlama etkinlikleri hakkında öğretmen görüşlerini araştırmıştır. Sonucunda, derslerinde robotik kodlama uygulatan öğretmenler, öğrencilerin derse katılımının ve tutumlarının olumlu yönde arttığını bunun yanı sıra akademik başarıyı, motivasyonu, bilişsel ve duyuşsal alandaki gelişimlerini de geliştirdiğini belirtmişlerdir.

Nitel sonuçlarda yine adaylar STEM uygulamaların ilgi çekici bulduklarını, yaratıcılıklarını geliştirdiğini, eğitimlerden zevk aldıklarını ve öğrendiklerini meslek hayatlarında çocuğa daha iyi öğretebilmek için gerekli öğrenme ortamları hazırlayabileceklerini belirtmişlerdir. Aynı zamanda el becerilerini geliştirdiği, yeni şeyler ürettiklerinden özgüvenlerinin arttı̆̆ını ve farklı bakış açısını geliştirdiğini belirtmişlerdir. Gazibeyoğlu (2018), STEM uygulamalarının 7.sınıf öğrencilerinin kuvvet ve enerji ünitesindeki başarılarına ve fen bilimlerine karşı tutumlarını incelemiştir. Sonuç olarak STEM' in uygulandığı 
derslerde öğrencilerin algılarının ve motivasyonlarının arttı̆̆ını derslerin eğlenceli, ve verimli geçtiğini, bilgiyi somutlaştırarak anlamlı ögrenmeler gerçekleştirdiklerini tespit etmiştir. Güldemir ve Çınar (2017), ortaokul öğrencilerinin ve fen bilimleri öğretmenlerinin STEM eğitiminin derslere entegresi yönündeki görüşlerini incelemişlerdir. Sonuç olarak öğrencilerin büyük bir kısmı STEM eğitiminin derslerde kullanılmasına yönelik olumlu görüşleri tespit etmişlerdir. Fen bilimleri öğretmenlerinin ise STEM uygulanan derslerde öğrencilerin derse aktif katılım gösterdiğini, öğrencinin kendini ifade edebilme becerisini geliştirdiğini ve fen dersinin tek başına değil diğer disiplinlerle ilişkilendirilerek verilmesinin önemini belirten görüşlere yer vermişlerdir. 
EXTENDED ABSTRACT

\title{
The Effects of Montessori Approach Based STEM Activities on Pre-service Teachers' Attitudes Towards Science and Science Teaching
}

\author{
Zehra Çakır - Sema Altun Yalçın \\ Erzincan Binali Yildırım University
}

In the age of science where technology is rapidly developing, it has been necessary to raise qualified individuals who can meet the needs and expectations of countries. This is possible with the effective realization of science education in educational programs. The better educational environments are designed for science education, the better that individuals can learn science permanently and effectively (Smith and Karr-Kidwell, 2000). Individuals who learn science will be able to use it in their daily lives by combining it with other disciplines. providing educational programs that are widely used in the world, in Turkey, while participating in the curriculum since 2017, it is a STEM education (Çepni, 2017). It has been observed that the creativity skills of preschool children are at the maximum level and the implementation of STEM applications in this period has an important effect on reaching the goals and achievements (Sackes Flevares, Gonya, and Trundle, 2012). Preschool games, concepts and skills that are desired to be acquired by the child can be given in a planned manner by using them in STEM applications. By allowing the child to ask questions and form hypotheses on the planned game, their knowledge and skills in STEM fields can be developed (Uyanık Balat \& Günşen, 2017).

It is thought that STEM education can be presented effectively in a teaching-learning environment prepared with the Montessori approach, which is applied in the preschool period and has common goals. The lack of sufficient research on this subject made it necessary to focus on this subject (Çakır, 2018). The Montessori approach is an approach developed by Maria Montessori on the basis of free education. It is an educational approach that has been implemented in the preschool education programs of many countries around the world, but has just started to work in our country, and has a positive effect 
on the development of children's cognitive, social and psychomotor skills (Eratay, 2009). It can be said that the Montessori approach, which is based on permanent learning in a natural educational environment, is an effective teaching approach that enriches the educational environment for STEM education, which is an interdisciplinary integrated learning (Elkin, Sullivan, and Bers, 2014). In this context, while educational approaches change in line with the needs in education systems, firstly, teachers should have sufficient knowledge in these areas. For this, it is very important for pre-school teacher candidates to have a strong content and pedagogical knowledge in Montessori and STEM fields and to be trained as experts who can integrate these fields with each other in their future professional lives (Çakır and Altun Yalçın, 2020).

The aim of the study is to determine the possible effects of Montessori approach-based STEM activities on pre-school teacher candidates' attitudes towards science and science teaching and their views on education.

The research was carried out with 50 teacher candidates studying in the pre-school department in the third grade in a university of a medium-sized city of Eastern Anatolia. In the study, pre-school teacher candidates were applied Montessori approach-based STEM activities. These trainings; It includes activities that can positively affect the attitudes of the teacher candidates towards science and science teaching and can be applied to the students in the future by using simple materials, types, legos and robotics with coding. The activities are composed of simple waste materials, robotic-coding Legos and types that can be found in all areas of daily life, including different application areas. These applications, which lasted 14 weeks in total, were carried out under the guidance of the researchers. In this application process, firstly, basic theoretical information about STEM education and Montessori approach was given to prospective teachers. Afterwards, groups of less than four people were formed for the activities determined by experts each week, and sufficient theoretical information about how to do about the activity (information such as science and mathematics required for the activity, information such as showing the shape of the activity with drawing) was introduced and the necessary materials were introduced and the applications were carried out.

The mixed method was used in order to support the effectiveness of the education whose effect was examined in the study with many evidences. The 
basis of the mixed method is to collect, combine and associate quantitative and qualitative data. Thus, researchers will not understand the research problem better and will conduct a longitudinal research (Creswell \& Tashakkori, 2007). In the study, as data collection tools, the Attitudes Towards Science Teaching Scale, Science Attitude Scale, and a semi-structured interview form consisting of 9 open-ended questions created by the researcher on the basis of quantitative scales were used. Paired samples t-test was used for quantitative data analysis of the study, and content analysis was used for qualitative data.

As a result of the research, a positive development was found in the attitudes of pre-school teacher candidates towards science and science teaching of Montessori-based STEM activities. It also supports quantitatively in the qualitative results of the study; The candidates have removed their prejudices towards science and have come to the level that they can integrate science and technology with their own fields, that the STEM and Montessori approach is suitable for providing meaningful learning for the child, that their selfconfidence and motivation towards the lesson have increased, they enjoy the trainings, that all group members have active participation, They stated that their scientific skills improved, that they learned how to look at the problem from different angles, that they found STEM applications interesting, that they developed their creativity, that they were provided with the opportunity to learn by doing, and that they provided permanent learning about the subject, and that they learned very well in putting a product into concrete. In addition, they stated that the skills that can prepare the necessary learning environments to teach the child better in future professional life have been formed.

\section{Kaynakça / References}

Açıkgöz, S. (2018). Fen eğitiminde okulöncesine yönelik yaklaşımlardan STEM ve Montessori yöntemlerinin öğretmen görüşleri doğrultusunda karşllaştırlmasl. Yüksek Lisans Tezi, Kastamonu Üniversitesi Fen Bilimleri Enstitüsü, Kastamonu.

Arastaman, G., Öztürk Fidan, İ. ve Fidan, T. (2018). Nitel araştırmada geçerlik ve güvenirlik: kuramsal bir inceleme, YYü Eğitim Fakültesi Dergisi, 15(1), 37-75.

Aslan, F. ve Bektaş, O. (2019). Fen bilgisi öğretmen adaylarını STEM uygulamaları hakkındaki görüşlerinin belirlenmesi. Uluslararası Eğitim Bilimleri Dergisi, 3(2), $17-50$. 
Bakırcı, H. ve Kutlu, E. (2018). Fen bilimleri öğretmenlerinin FeTeMM yaklaşımı hakkındaki görüşlerinin belirlenmesi. Türk Bilgisayar ve Matematik Eğitimi Dergisi, 9(2), 367-389.

Bybee, R. W. (2010). What is STEM?. Science Education, 329(5995), 996-996.

Büyüköztürk, Ş., Kılıç- Çakmak, E., Akgün, Ö. E., Karadeniz, Ş. ve Demirel, F. (2016). Bilimsel araştırma yöntemleri. 21. Baskı. Ankara: Pegem Yayıncilk.

Can, A. (2016). SPSS ile bilimsel araştırma sürecinde nicel veri analizi. 6. Baskı, Pegem Akademi.

Cho, H. Kim, J. ve Choi, D.H(2003). Eaarly childhood teachers' attitudes toward science teaching: A scale validation study. Educational Research Quarterly, 27(2), 33-42

Creswell, J.W. (2002). Educational research: Planning, conducting, and evaluating quantitative and qualitative approaches to research. Upper Sadle River, NJ: Merrill/Pearson Education.

Creswell, J. W. ve Tashakkori, A. (2007). Differing perspectiveson mixed methods research. Journal of Mixed Methods Research, 1(4), 303-308.

Çakır, Z. (2018). Montessori yaklaşım temelli STEM etkinliklerinin okul öncesi öğretmen adaylar üzerindeki etkisinin incelenmesi. Yüksek Lisans Tezi, Erzincan Binali Yıldırrm Üniversitesi Fen Bilimleri Enstitüsü, Erzincan.

Çakır, Z., Yalçın, S. A. ve Yalçı, P. (2020). Montessori yaklaşımı temelli STEM etkinliklerinin okul öncesi öğretmen adaylarınn eleştirel düşünme becerilerine etkisi. Fen Bilimleri Öğretim Dergisi, 8(1), 18-45.

Çalık, H. (2020). Fen bilgisi öğretmen adaylarnnn STEM etkinlikleri ve stem temelli robotik etkinliklerinin hipotetik- yaratıc akal yürütme becerisi, yaşam boyu öğrenme ve yapılandırmacı öğrenme gelişimine etkisinin incelenmesi. Erzincan Binali Ylldırm Üniversitesi Fen Bilimleri Enstitüsü, Erzincan.

Çamlıbel Çakmak, Ö. (2006). Okul öncesi öğretmen adaylarnnı fene ve fen öğretimine yönelik tutumlar ile bazı fen kauramlarm anlama düzeyleri arasındaki ilişkinin incelenmesi. Yayımlanmamış Yüksek Lisans Tezi, Abant İzzet Baysal Üniversitesi, Sosyal Bilimler Enstitüsü, Bolu

Çepni, S. (2017). Kuramdan uygulamaya STEM+A+E eğitimi. 1. Baskı. Ankara: Pegem Akademi.

Çevik, M., Danıştay, A. ve Yağcı, A. (2017). Ortaokul öğretmenlerinin FeTeMM (fenteknoloji-mühendislik-matematik) farkındalıklarının farklı değişkenlere göre değerlendirilmesi. Sakarya University Journal of Education, 7(3), 584-599. 
Çömek, A. ve Avcı, B. (2016). Fen eğitiminde robotik uygulamaları hakkında öğretmen görüşleri. Yükseköğrenim Üzerine, Internatıonal Congress On New Trends In Higher Education: Keeping Up With The Change, A. M. GER ed., İstanbul Aydın Üniversitesi Yayınları, İstanbul, 104-115.

Elkin, M., Sullivan, A. ve Bers, M. U. (2014). Implementing a robotics curriculum in an early childhood Montessori classroom. Journal of Information Technology Education: Innovations in Practice, 13, 153-169.

Eratay, E. (2009). Montessori yönteminin etkililiği. Abant İzzet Baysal Üniversitesi, Eğitim Fakültesi, 19. Ulusal Özel Ĕ̆itim Kongresinde poster bildiri olarak sunulmuştur. Marmaris, 22-24 Ekim.

Gazibeyoğlu, T. (2018). STEM uygulamalarmm 7.smnföğrencilerinin kuvvet ve enerji ünitesindeki başarlarna ve fen bilimleri dersine karşı tutumlarma etkisinin incelenmesi. Yüksek Lisans Tezi, Kastamonu Üniversitesi Fen Bilimleri Enstitüsü, Kastamonu.

Geban, Ö., Ertepınar, H., Yılmaz, G., Altın, A. ve Şahbaz, F. (1994). Bilgisayar destekli eğitimin öğrencilerin fen bilgisibaşarılarına ve fen bilgisi ilgilerine etkisi. Ulusal Fen Bilimleri Eğitimi Sempozyumu: Bildiri Özetleri Kitabı, 1-2.

Güldemir, S. ve Çınar S. (2017). Fen bilimleri öğretmenleri ve ortaokul öğrencilerinin STEM etkinlikleri hakknndaki görüşleri. ULEAD 2017 Annual Congress: ICRE, 280-286.

Greenfield, D. B., Jirout, J., Dominguez, X., Greenberg, A., Maier, M., ve Fuccilo, J. (2009). Science in the preschool classroom: A programmatic research agenda to improve science readiness. Early Education and Development, 20(2), 238-264.

Koyunlu Ünlü, Z. ve Dere, Z. (2018). Okul öncesi öğretmen adaylarının hazırladıkları FeTeMM etkinliklerinin değerlendirilmesi. Ahi Evran Üniversitesi Kırşehir Eğitim Fakültesi Dergisi, 19(2), 1502-1512.

Lamb, R., Akmal, T. ve Petrie K. (2015). Development of a cognition-priming model describing learning in a STEM classroom. Journal of Research in Science Teaching. https://doi.org/10.1002/tea.21200.

Linder, S. M., Ramey, M.D. ve Zambak, S. (2013). Predictors of school readiness in literacy and mathematics: A selective review of the literatüre. Early Childhood Research and Practice 15(1).

Ricks, M. M. (2006). A study of the impact of an informal science education program on middle school students' science knowledge, science attitude, STEM high school and college course selections, and career decisions. Doktoral Thesis. The University of Texas, Austin. 
Saad, M. E. (2014). Progressing science, technology, engineering, and math (STEM) education in North Dakota with near-space ballooning. Master Thesis. Master of Science Grand Forks, North Dakota.

Sackes, M. Flevares, L. M., Gonya, M. ve Trundle, K. C. (2012). Preservice early childhood teachers' sense of efficacy for integrating mathematics and science: Impact of a methods course. Journal of Early Childhood Teacher Education, 33(4), 349364.

Smith, J. ve Karr-Kidwell, P. J. (2000). The interdisciplinary curriculum: A literary review and a manual for administrators and teachers. ERIC, Number: ED443172.

Şahin, A. (2013). STEM clubs and science fair competitions: Effects on post-secondary matriculation. Journal of STEM Education, 14(1).

Şan, E. (2020). Türkiye' de eğitim alaninda yayınlanan karma yönteme dayalı makalelerin incelenmesi. Yüksek Lisans Tezi, Maltepe Üniversitesi Lisansüstü Eğitim Enstitüsü. İstanbul.

Tezel, Ö. ve Yaman, H. (2017). FeTeMM eğitimine yönelik türkiye'de yapılan çalışmalardan bir derleme. Ĕgitim ve Öğretim Araştrrmalan Dergisi, Haziran, 6(1), ISSN: 2146-9199.

TÜSİAD, (2014). STEM alanında eğitim almıss işgücüne yönelik talep ve beklentiler araştırması. 10-557.

Thompson, C. L. veShrigley, R. L. (1986). What Research Says: Revising the Science Attitude Scale. School Science and Mathematics, 86(4), 331-43.

Uyanık Balat, G. ve Günşen, G. (2017). Okul öncesi dönemde STEM yaklaşımı. Akademik Sosyal Araştrmalar Dergisi, 5(42), 337-348.

Wyss, V. L., Heulskamp, D. ve Siebert, C. J. (2012). Increasing middle school student interest in STEM careers with videos of scientists. International Journal of Environmental and Science Education, 7(4), 501-522.

Yamak, H., Bulut, N. ve Dündar, S. (2014). 5. sinff öğrencilerinin bilimsel süreç becerileri ile fene karşı tutumlarına FeTeMM etkinliklerinin etkisi. Gazi Eğitim Fakültesi Dergisi, 34(2), 249-265.

Yıldırım Doğru, S. S. (2009). Özel eğitimde kullanılan alternatif programlar (Montessori Yaklaşımı). Tübav Bilim Dergisi, 2(1), 107-116.

Yıldırım, A. ve Şimşek, H. (2008). Sosyal bilimlerde nitel araştırma yöntemleri. Seçkin Yayıncilk. Ankara. (6. Baskı). 


\section{Kaynakça Bilgisi / Citation Information}

Çakır, Z. ve Altun Yalçın, S. (2021). Montessori yaklaşımı temelli stem etkinliklerinin öğretmen adaylarının fene ve fen öğretimine yönelik tutumlarına etkisi. OPUS-Uluslararası Toplum Araştırmaları Dergisi, 17(35),1895-1924. DOI: 10.26466/opus.831879 